\title{
Soil microbes mediate the effects of nitrogen supply and co-inoculation on Barley Yellow Dwarf Virus in Avena sativa
}

Casey A. Easterday ${ }^{1,2}$, Amy E. Kendig ${ }^{1,3}$, Christelle Lacroix ${ }^{1,4}$, Eric W. Seabloom ${ }^{1}$, and Elizabeth T. Borer ${ }^{1}$

1. Department of Ecology, Evolution, and Behavior, University of Minnesota, St. Paul, MN USA

2. Current address: Carlson School of Management, University of Minnesota, Minneapolis, MN

3. Current address: Agronomy Department, University of Florida, Gainesville, FL USA

4. Current address: INRAE, Pathologie Végétale, F-84140, Montfavet, France

Corresponding author: AEK (aekendig@gmail.com)

Total word count: 5156

Section word counts:

Introduction: 1057

Materials and Methods: 1840

Results: 719

Discussion: 1540

Figures: 5

Tables: 5

Supporting Information: Appendix S1 (Tables S1-S2, Figure S1) 


\section{Summary}

- Nutrient supply rates to hosts can mediate host-pathogen interactions. In terrestrial systems, nutrient supply to plants is mediated by soil microbes, suggesting a potential indirect effect of soil microbes on plant-pathogen interactions. Soil microbes also may affect plant pathogens by inducing plant defenses.

- We tested the role of soil microbes, nitrogen supply to plant hosts, and co-inoculation on infection by aphid-vectored RNA viruses, Barley Yellow Dwarf Virus (BYDV-PAV) and Cereal Yellow Dwarf Virus (CYDV-RPV), in a grass host grown in soil microbes collected from a long-term nitrogen enrichment experiment.

- BYDV-PAV incidence declined with high nitrogen supply, co-inoculation, or presence of soil microbes exposed to long-term low nitrogen enrichment. However, when combined, the negative effects of these treatments were sub-additive: nitrogen and co-inoculation did not reduce BYDV-PAV incidence in plants grown with the soil microbes. While soil microbes impacted leaf chlorophyll, they did not alter biomass or CYDV-RPV incidence.

- Soil microbes mediated the effects of nitrogen supply and co-inoculation on infection incidence and the effects of infection on host symptoms. Thus, soil microbial communities can indirectly control disease dynamics, altering the effects of nitrogen enrichment on plant-pathogen and pathogen-pathogen interactions in terrestrial systems.

Key words: Avena sativa, Barley and Cereal Yellow Dwarf Viruses, microbial interactions, nitrogen, pathogen interactions, Rhopalosiphum padi, soil microbes, vectored plant pathogen 


\section{Introduction}

Fossil fuel use and fertilizer production have more than doubled reactive nitrogen $(\mathrm{N})$ inputs to terrestrial ecosystems since pre-industrialization (Vitousek et al., 1997; Galloway et al., 2004). Nitrogen enrichment can profoundly impact terrestrial plant systems, increasing productivity and reducing biodiversity (Elser et al., 2007; Midolo et al., 2019). Further, the effects of $\mathrm{N}$ enrichment on plants can have repercussions throughout food webs (Sedlacek et al., 1988; Ritchie, 2000; He \& Silliman, 2015). For example, N enrichment can modify plantpathogen interactions (Dordas, 2009; Veresoglou et al., 2013) and interactions among different pathogens that co-infect plants (Lacroix et al., 2014; Kendig et al., 2020). The communities of pathogens that rely on plants can in turn impact plant productivity, community composition, and ecosystem processes (Lovett et al., 2010; Paseka et al., 2020; Borer et al., 2021). However, a key component of terrestrial systems - soil microbes - have been neglected in many studies of $\mathrm{N}$ enrichment on aboveground plant pathogens. Soil microbes affect plant access to N (van der Heijden et al., 2008; Kuzyakov \& Xu, 2013) and plant interactions with above- and belowground pathogens (van Loon et al., 1998; Berendsen et al., 2012). Therefore, laboratory-based studies that do not include natural soil microbial communities may under- or over-estimate the effects of $\mathrm{N}$ enrichment on plant-pathogen interactions under field conditions. Moreover, $\mathrm{N}$ enrichment can change the nature of interactions between soil microbes and plants through time (Johnson, 1993; Keeler et al., 2008; Weese et al., 2015; Huang et al., 2019). Consequently, even studies that include natural soil microbial communities may mis-characterize the impacts of $\mathrm{N}$ enrichment on plant pathogen communities if they do not encompass long enough time scales.

Nitrogen is an essential component of the genetic material and proteins in plants and microbes (Sterner \& Elser, 2002). Changes in N availability can therefore modify the fitness of plants (Johnson, 1993; Welch \& Leggett, 1997), microbes (Schimel \& Bennett, 2004; Kuzyakov $\& \mathrm{Xu}, 2013$ ), and insect vectors of plant pathogens (Nowak \& Komor, 2010; Bogaert et al., 2017). Because plants, their pathogens, and the insect vectors of pathogens rely on N, N enrichment can increase or decrease infection prevalence (Seabloom et al., 2010; Borer et al., 2014), pathogen load (Singh, 1970; Hoffland et al., 2000; Mitchell et al., 2003; Robert et al., 2004; Fagard et al., 2014; Whitaker et al., 2015) and disease resistance (Dietrich et al., 2004; Bellin et al., 2013; Mur et al., 2016). Further, individual plants and plant communities frequently host multi-pathogen communities (Seabloom et al., 2009; Bass et al., 2019) which may shift in 
composition with $\mathrm{N}$ enrichment (Lacroix et al., 2014; Kendig et al., 2020). Soil microbes and $\mathrm{N}$ enrichment may interact to affect plant-pathogen and pathogen-pathogen interactions. For example, fertilizer and green manure can increase the disease-suppressive activity of foliar and rhizosphere microbial communities (Wiggins \& Kinkel, 2005; Berg \& Koskella, 2018).

Soil microbes may mediate plant-pathogen interactions by altering the amount of $\mathrm{N}$ available to the plant. Soil microbes can increase plant access to $\mathrm{N}$ through $\mathrm{N}$ fixation, $\mathrm{N}$ mineralization, and extending root networks (van der Heijden et al., 2008), and they also may compete with plants for N (Schimel \& Bennett, 2004; Kuzyakov \& Xu, 2013). N enrichment can reduce the benefits plants receive from microbial mutualists (Johnson, 1993; Weese et al., 2015), although losses can be offset by the direct benefits of bioavailable N (Johnson, 1993; Farrer \& Suding, 2016). N enrichment has variable effects on N mineralization rates (Mueller et al., 2013; Chen et al., 2019), mediated by changes in soil microbial community composition and $\mathrm{pH}$ (Chen et al., 2019). Over decadal time scales, $\mathrm{N}$ enrichment can drive large compositional and evolutionary changes in soil microbial communities that affect their N-related interactions with plants (Klinger et al., 2016; Huang et al., 2019). For example, $\mathrm{N}$ enrichment can shift the relative abundance of archaea and bacteria that oxidize ammonia, depending on the form of $\mathrm{N}$ added (Leff et al., 2015; Moreau et al., 2015).

Soil microbial communities can contain plant pathogens as well as microbes that suppress plant pathogens (Schlatter et al., 2017). Soil microbes can suppress soil-borne pathogens via competition for resources, interference with pathogen signaling, or production of antibiotic compounds and lytic enzymes (Lugtenberg \& Kamilova, 2009; Berendsen et al., 2012). In addition, beneficial and pathogenic soil microbes can induce disease resistance pathways in plants, priming them for faster and stronger responses to aboveground pathogen attacks (van Loon et al., 1998; Pieterse et al., 2014; Mauch-Mani et al., 2017). Soil biota associated with induced disease resistance include bacteria in the genera Pseudomonas, Serratia, and Bacillus and fungi in the genera Trichoderma, Fusarium, Piriformospora, and Glomeromycota (Pieterse et al., 2014; Mauch-Mani et al., 2017). Nitrogen enrichment may modify the effects of soil microbes on plant diseases through compositional or evolutionary shifts in microbial communities or changes in microbe-pathogen interactions (Otto-Hanson et al., 2013; Schlatter et al., 2013; Klinger et al., 2016; Huang et al., 2019). For example, $\mathrm{N}$ enrichment can reduce the abundance and colonization rates of arbuscular mycorrhizal fungi (AMF), which includes the 
genus Glomeromycota (Treseder, 2004; Leff et al., 2015; Jia et al., 2020). In contrast, N enrichment tends to increase phyla and classes containing some groups of fungi (Trichoderma and Fusarium) and bacteria (Pseudomonas, Serratia, and Bacillus) that induce disease resistance (Fierer et al., 2012; Ramirez et al., 2012; Leff et al., 2015; Chen et al., 2019).

Here, we evaluated the effects of soil microbial communities on N-dependent changes in plant-pathogen and pathogen-pathogen interactions, using two widespread and economically important insect-vectored plant viruses (BYDV-PAV and CYDV-RPV). We used aphids (Rhopalosiphum padi) to inoculate oat plants (Avena sativa) with these Barley and Cereal Yellow Dwarf Viruses (B/CYDV's) across a full factorial combination of N supply rates (low or high) and soil microbial communities collected from soils subjected to different levels of longterm $\mathrm{N}$ fertilization rates (ambient, low, or high). For each treatment, we measured virus incidence (i.e., the proportion of plants that became infected), plant biomass, and leaf chlorophyll content. We addressed three questions: (1) What are the effects of $\mathrm{N}$ on single infection and coinfection incidence in plants grown in sterile soil? (2) Do soil microbes mediate the effects of $\mathrm{N}$ on single infection and co-infection incidence? (3) Do soil microbes mediate the effects of $\mathrm{N}$ or infection on host traits?

\section{Materials and Methods}

Study system

B/CYDVs, generalist pathogens of the Luteoviridae family, cause systemic infections in over 150 grass species in the Poacaea family, stunting growth, yellowing or reddening leaves, and reducing fecundity (Carrigan et al., 1983; Irwin \& Thresh, 1990; D’Arcy \& Burnett, 1995). B/CYDVs comprise members of the Luteovirus (BYDVs) and Polerovirus (CYDVs) genera (Miller et al., 2002). BYDV-PAV and CYDV-RPV are considered representative members of each genera and have been the foci of many studies (Power et al., 1991; Seabloom et al., 2009; Lacroix et al., 2014; Kendig et al., 2020). These viruses are transmitted by a range of aphid vectors, including Rhopalosiphum padi that transmits both BYDV-PAV and CYDV-RPV (D'Arcy \& Burnett, 1995). Importantly, these viruses are strictly insect-vectored; they cannot be transmitted to plants via soil. We used A. sativa L. cv. Coast Black Oat as our plant host species. Avena sativa can host AMF (Yang et al., 2010) and AMF were found to have a positive effect on BYDV-PAV titer in Avena fatua under elevated $\mathrm{CO}_{2}$ (Rúa et al., 2013). Soil microbes were 
collected from Cedar Creek Ecosystem Science Reserve and Long-Term Ecological Research (LTER) site (CDR; see next section). Prior to conducting this work, we established that both of our focal viruses are present in natural communities at CDR. In 2009, we haphazardly collected 153 plants of 10 different grass species across CDR to determine which B/CYDV's were present. We assessed infection status via ELISA as detailed in Seabloom et al. (2009). Overall infection prevalence of PAV was 0.17 and RPV was 0.03 .

\section{Soil microbes}

In June 2014, we collected soil cores from a long-term experiment in a successional grassland at CDR (experiment "E001", www.cedarcreek.umn.edu; Bethel, MN, USA). Cedar Creek has sandy, N-limited soils and a background wet $\mathrm{N}$ deposition rate of approximately $6 \mathrm{~kg}$ $\mathrm{N} \mathrm{ha}^{-1}$ year $^{-1}\left(58 \% \mathrm{NH}_{4}, 42 \% \mathrm{NO}_{3}\right)$ (Tilman, 1987; Clark \& Tilman, 2008). We collected soils from field A, which was abandoned from agriculture in 1968 and burned annually beginning in 2005. These plots had received annual additions of $\mathrm{P}, \mathrm{K}, \mathrm{Ca}, \mathrm{Mg}, \mathrm{S}$, and citrate-chelated trace metals since 1982 and three levels of $\mathrm{N}$ fertilizer: 0, 34, or $270 \mathrm{~kg} \mathrm{~N} \mathrm{ha}^{-1} \mathrm{yr}^{-1}$ (see Tilman, 1987 for details). In this experiment, $\mathrm{N}$ fertilization has increased plant biomass and soil $\mathrm{N}$ concentration and decreased plant species richness (Isbell et al., 2013a,b). We randomly sampled three plots for each $\mathrm{N}$ fertilization rate (Fig. S1) and six locations within each $4 \times 4 \mathrm{~m}$ plot to extract a soil core $(1.9 \mathrm{~cm}$ diameter and $10 \mathrm{~cm}$ deep $)$. In the lab, soil cores were passed through a $4 \mathrm{~mm}$ sieve, then twice through a $2 \mathrm{~mm}$ sieve to remove coarse debris and roots, and then combined based on their $\mathrm{N}$ fertilization rate.

Next, we prepared soil microcosms by filling four large, surface sterilized bins with $17 \mathrm{~L}$ of potting soil composed of $70 \%$ Sunshine medium vermiculite (vermiculite and less than 1\% crystalline silica; Sun Gro Horticulture, Agawam, MA, USA) and 30\% Turface MVP (calcined clay containing up to $30 \%$ crystalline silica; Turface Athletics, Buffalo Grove, IL, USA), saturated with tap water (approximately $5 \mathrm{~L}$ for every $20 \mathrm{~L}$ of dry soil) and autoclaved at $121^{\circ} \mathrm{C}$ and 15 psi for 60 minutes to kill the naturally existing microbial consortium. We then mixed 350 $\mathrm{mL}$ of field soil from each $\mathrm{N}$ fertilization level separately into the bins. Field soil comprised approximately $2 \%$ of the bin soil volume. We did not mix field soil into the fourth bin. Lastly, we covered the bins with non-airtight lids and incubated the soil at $25^{\circ} \mathrm{C}$ for 11 days. 


\section{Experimental setup and implementation}

For each of the four soil microcosms, we filled 80 conical plastic pots $(3.8 \mathrm{~cm}$ diameter $\mathrm{x}$ $21 \mathrm{~cm}$ depth, $164 \mathrm{ml}$ ) with soil mixture and planted one $A$. sativa seed per pot $4.5 \mathrm{~cm}$ from the surface of the soil. Seeds were obtained from the USDA (National plant germplasm system, USDA; USA) in June 2013 and were surface sterilized with 12.5\% bleach solution. Then, we haphazardly assigned plants to later receive one of two $\mathrm{N}$ supply rates $\left(7.5 \mu \mathrm{M} \mathrm{NH} \mathrm{NO}_{3}\right.$ was "low N" and $375 \mu \mathrm{M} \mathrm{NH}_{4} \mathrm{NO}_{3}$ was "high N"; Table S1) and one of four virus inoculations (BYDV-PAV, CYDV-RPV, co-inoculation, or mock inoculation), leading to ten replicates per treatment. Plants grew in a growth chamber containing only healthy plants with a 16:8 h light:dark cycle at $19-20^{\circ} \mathrm{C}$ under Lumilux high pressure sodium ET18 bulbs for 11 days. Two days after planting, we watered the pots with $30 \mathrm{ml}$ of the modified Hoagland solution (Hoagland \& Arnon, 1938; Lacroix et al., 2014; Table S1) corresponding to the plant's assigned N supply rate. We watered plants with these solutions twice per week until harvest.

When the plants had been growing for 22 days, we used $R$. padi aphids to inoculate them with BYDV-PAV, CYDV-RPV, both viruses, or to perform a mock inoculation. Rhopalosiphum padi were obtained from Dr. G. Heimpel at the University of Minnesota (St. Paul, MN, USA) and reared on $A$. sativa in growth chamber conditions described above (except with $28 \mathrm{~W}$ Ultramax EcoXL lights). BYDV-PAV and CYDV-RPV isolates were obtained from Dr. S. Gray at Cornell University (Ithaca, NY, USA) in January 2013. They were also maintained in A. sativa plants in similar growth chamber conditions (except with $40 \mathrm{~W}$ cool white light bulbs). We inoculated plants by allowing aphids to feed on either BYDV-PAV- or CYDV-RPV-infected $A$. sativa tissue in $25 \mathrm{~mL}$ glass tubes sealed with corks for approximately 48 hours. Then, we transferred the aphids to $2.5 \times 8.5 \mathrm{~cm}, 118 \mu \mathrm{m}$ polyester mesh cages secured to one leaf on each experimental plant with Parafilm and bobby pins. Ten aphids were used to inoculate each plant, with 5 carrying each virus for the co-inoculation treatment, five viruliferous (carrying virus) and five non-viruliferous aphids for each single virus treatment, and ten non-viruliferous aphids for the mock inoculation treatment. We allowed aphids to feed on the experimental plants for approximately 96 hours, after which we manually killed all aphids and removed the cages. Plants grew for 19 more days before we took measurements. To estimate $\mathrm{N}$ stress through leaf chlorophyll content (Zhao et al., 2015), we took three measurements per plant with a SPAD-502 Meter (Soil Plant Analysis Development; Konica Minolta, Tokyo, Japan). Then, we harvested 
and weighed the aboveground biomass, which we stored at $-20^{\circ} \mathrm{C}$ until it was analyzed for virus infection.

\section{Detection of $B / C Y D V$ infection}

To extract total RNA, we ground approximately $50 \mathrm{mg}$ of leaf tissue in a bead-beater with a copper BB and $1 \mathrm{ml}$ of TRIzol ${ }^{\mathrm{TM}}$ Reagent (Invitrogen ${ }^{\mathrm{TM}}$, Thermo Fisher Scientific, Waltham, MA, USA) per the manufacturer's instructions. We then purified RNA from the cellular components following the extraction protocol published by Lacroix et. al. (2014). We resuspended the purified RNA in nuclease-free water and stored the samples at $-20^{\circ} \mathrm{C}$ until performing the reverse transcription polymerase chain reaction (RT-PCR). We used a nanodrop spectrophotometer (Thermo Fisher Scientific) to quantify the concentration of RNA within each sample and then performed a multiplex RT-PCR assay to isolate and amplify BYDV-PAV and CYDV-RPV nucleic acids as published previously (Deb \& Anderson, 2008; Lacroix et al., 2014).

We combined $5 \mu \mathrm{l}$ of each PCR product with $2 \mu \mathrm{l}$ of $6 \mathrm{X}$ loading dye (Genesee Scientific, El Cajon, CA, USA) and loaded the samples and 100 bp DNA ladder (Apex Bioresearch Products, North Liberty, IA, USA) into an Agarose-1000 gel (Invitrogen, Thermo Fisher Scientific) stained with 2\% SybrSafe (Invitrogen, Thermo Fisher Scientific). After 25 minutes at $120 \mathrm{~V}$, we observed the gel with a UV-light EZ doc system (Bio-Rad Laboratories, Hercules, CA, USA) to detect bands at $298 \mathrm{bp}$ and $447 \mathrm{bp}$, indicating the presence of BYDV-PAV and CYDV-RPV, respectively.

\section{Statistical analyses}

We assessed the effects of the experimental treatments on the infection incidence of BYDV-PAV and CYDV-RPV (i.e., the proportion of plants infected out of those inoculated) using binomial (logit-link) generalized linear regressions with virus infection as a binary response variable and soil microbe inoculum (sterilized, ambient N, low N, or high N), N supply (binary variable), whether the plants were co-inoculated (binary variable), and their interactions as independent variables. The intercepts represented singly inoculated plants grown in sterile soil with low $\mathrm{N}$ supply. We tested the effects of $\mathrm{N}$ supply and soil microbe inoculum on co-infection incidence using an analogous procedure. Samples with an infection inconsistent with the 
inoculation treatment were removed from analyses. Inconsistent infections likely arose from small aphids escaping cages during the inoculation period and occurred in 31 of 229 plants (Table S2). Treatment sample sizes in the final dataset ranged from seven to ten.

To assess the effects of the experimental treatments on the A. sativa plants, we used linear regressions with log-transformed biomass and log-transformed chlorophyll content as response variables and $\mathrm{N}$ supply, soil microbe inoculum, successful inoculation treatment (mock, BYDV-PAV only, and CYDV-RPV only), and their interactions as the independent variables. Therefore, we omitted plants from analyses that were unsuccessfully inoculated, either because the intended infection was not detected or because an unintended infection was detected (Table S2). Co-infected plants were omitted from analyses due to limited sample sizes. The chlorophyll values used in the model were the averages of three measurements taken per plant. The intercepts represented mock-inoculated plants grown in sterile soil with low N supply. Treatment sample sizes in the final dataset ranged from three to nine.

All regressions described above were fit using Bayesian models with the brms package in R version 4.0.2 (Bürkner, 2017; R Core Team, 2020). Models had three chains of 6000 iterations each with a 1000 iteration burn-in period. Gaussian distributions with a mean of zero and a standard deviation of ten were used as prior distributions for intercepts and coefficients (very weakly informative; McElreath, 2015). We used a half Student's $t$-distributions with three degrees of freedom, a location of zero, and a scale of ten as the prior distribution for the residual standard deviations (Bürkner, 2017). We assessed model fit by ensuring that $r$-hat values were equal to one, that the three chains were well mixed, and that simulated data from the posterior predictive distributions were consistent with observed data. In the results, we present point estimates with $95 \%$ highest posterior density intervals based on posterior samples of model coefficients in brackets.

To evaluate the effect of sample size on the probability of detecting an effect with quantile-based $95 \%$ credible intervals that omit zero, we simulated 1000 datasets of the same sample sizes and with the mean effect size measured in the experiment. We fit regressions to each dataset and calculated the number of times the $95 \%$ credible intervals of the variable of interest omitted zero (Kurz, 2019). We repeated the analysis with multiple sample sizes. We performed this analysis for the effects of CYDV-RPV infection on log-transformed plant biomass, where the mean difference was -0.23 , the sample sizes were 8 (mock-inoculated, low $\mathrm{N}$ 
supply, sterile soil) and 6 (CYDV-RPV infected, low N supply, sterile soil), and the regression was a normal linear regression with infection status as the independent variable.

\section{Results}

The effects of $N$ on infection incidence in sterile soils

BYDV-PAV incidence of singly inoculated plants grown with low N supply was 0.96 [0.84, 1.00] (Fig. 1a). High N supply reduced BYDV-PAV incidence in singly inoculated plants to $0.61(-36 \%[-72 \%,-4.0 \%])$ and co-inoculation reduced BYDV-PAV incidence to $0.32(-66 \%$ [-93\%, -38\%], Fig. 1a). However, high N supply did not affect BYDV-PAV incidence of coinoculated plants (estimated change relative to low N supply: 56\% [-83\%, 283\%]), leading to an interaction between $\mathrm{N}$ supply and co-inoculation (Table 1). CYDV-RPV incidence of singly inoculated plants grown with low $\mathrm{N}$ supply was 0.66 [0.38, 0.93] (Fig. 2a). Co-inoculation reduced CYDV-RPV incidence to $0.11(-83 \%$ [-100\%, -53\%], Fig. 2a). Nitrogen supply did not affect CYDV-RPV incidence in singly or co-inoculated plants (Table 2). The average coinfection incidence of co-inoculated plants grown in sterile soil with low $\mathrm{N}$ supply was 0.10 $[0.00,0.28]$. Nitrogen supply did not affect co-infection incidence (Fig. 3a, Table 3).

\section{Soil microbes $x$ : effects on infection incidence}

Inoculation with microbes from low $\mathrm{N}$ fertilization field soils ("low $\mathrm{N}$ microbes") reduced BYDV-PAV incidence to $0.47[0.18,0.77]$, a $51 \%$ decrease $[-83 \%,-20 \%]$ relative to singly inoculated plants grown in sterile soils with low $\mathrm{N}$ supply (Fig. 1c). In contrast to the negative effect of high $\mathrm{N}$ supply when plants were grown in sterile soil (Fig. 1a), high $\mathrm{N}$ did not affect BYDV-PAV incidence when plants were grown with low $\mathrm{N}$ microbes (estimated change relative to low $\mathrm{N}$ supply: 109\% [-37\%, 310\%], Fig. 1c), leading to an interaction between $\mathrm{N}$ supply and low N microbes (Table 1). Similarly, high N supply did not affect BYDV-PAV incidence when plants were grown with ambient $\mathrm{N}$ microbes (estimated change relative to low $\mathrm{N}$ supply: $-38 \%$ [-91\%, 22\%], Fig. 1b) or high N microbes (estimated change relative to low N supply: $-0.27 \%$ [-9.4\%, 5.4\%], Fig. 1d), but there was no statistical interaction between $\mathrm{N}$ supply and these microbe treatments (Table 1). In contrast to plants grown with sterile soil (Fig. 1a), coinoculation did not affect BYDV-PAV incidence when plants were grown with low $\mathrm{N}$ microbes (estimated change relative to single inoculation: $21 \%[-75 \%, 158 \%]$, Fig. 1c) or ambient $\mathrm{N}$ 
microbes (estimated change relative to single inoculation: $-27 \%$ [-80\%, 32\%], Fig. 1b), leading to interactions between co-inoculation and each of the microbe treatments (Table 1). However, co-inoculation reduced BYDV-PAV incidence from 0.99 to $0.70(-29 \%$ [-57\%, -4.9\%]) when plants were grown with high N microbes (Fig. 1d). High N supply did not affect BYDV-PAV incidence of co-inoculated plants grown with any of the microbe treatments (Table 1). Microbes in field soils did not affect CYDV-RPV incidence (Fig. 2b-d, Table 2) or co-infection incidence (Fig. 3b-d, Table 3) relative to sterile soil.

Soil microbes $x N$ and soil microbes $x$ infection: effects on the host

The average aboveground biomass of mock-inoculated plants grown in sterile soil with low $\mathrm{N}$ was 0.20 g [0.14 g, 0.28 g] (Fig. 4a). High N supply increased biomass to $0.37 \mathrm{~g}$, a $90 \%$ increase $[-0.75 \%, 185 \%$ ] (Fig. 2a, Table 4). Infection and soil microbes did not significantly affect aboveground biomass (Table 4). CYDV-RPV infection reduced aboveground biomass on average, but the $95 \%$ credible intervals included zero. Only $9.8 \%$ of simulated datasets of the same sample sizes used in the experiment had $95 \%$ credible intervals that omitted zero. In contrast, sample sizes ten times of those in the experiment produced $95 \%$ credible intervals that omitted zero in $72.3 \%$ of simulated datasets.

The average leaf chlorophyll content of mock-inoculated plants grown in sterile soil with low N was 23 SPAD [21 SPAD, 25 SPAD] (Fig. 3a). High N supply increased leaf chlorophyll content to 27 SPAD, a 19\% increase [4\%, 35\%] (Fig. 3a, Table 5). Infection did not significantly affect leaf chlorophyll content of plants grown in sterile soil (Fig. 3a, Table 5), but BYDV-PAV infection reduced leaf chlorophyll content from 24 SPAD to 19 SPAD, a $21 \%$ decrease [-34\%, 7.3\%], for plants grown with microbes from ambient $\mathrm{N}$ field soils (Fig. 3b). However, when plants were grown with high $\mathrm{N}$ supply and ambient $\mathrm{N}$ microbes, BYDV-PAV infection did not affect leaf chlorophyll content (estimated change relative to single infection: $-7 \%$ [-24\%, 9\%], Fig. 3b), leading to a significant three-way interaction among ambient $\mathrm{N}$ microbes, $\mathrm{N}$ supply, and BYDV-PAV infection (Table 5).

\section{Discussion}

Human activities have dramatically increased N supply to terrestrial ecosystems, with consequences for plant communities, plant-pathogen interactions, and pathogen-pathogen 
interactions (Elser et al., 2007; Veresoglou et al., 2013; Smith, 2014; Midolo et al., 2019). Although soil microbes can mediate $\mathrm{N}$ availability, soilborne pathogens, and plant defenses (van der Heijden et al., 2008; Kuzyakov \& Xu, 2013; Mauch-Mani et al., 2017), the indirect effects of soil microbes on aboveground pathogen communities and host-pathogen interactions have received little attention. Our experimental manipulation of $\mathrm{N}$ supply, soil microbe inoculum, and virus infection demonstrated that soil microbes can influence aboveground plant-pathogen and pathogen-pathogen interactions and mediate the impact of infection on plant traits. Specifically, soil microbes exposed to long-term low $\mathrm{N}$ enrichment mediated the effects of $\mathrm{N}$ supply and coinoculation on infection incidence and plant chlorophyll content. Surprisingly, soil microbes did not affect aboveground plant biomass, and they had different impacts on the incidence of two related viral pathogens.

Soil microbes reduced BYDV-PAV incidence and counteracted the negative effects of $\mathrm{N}$ supply and co-inoculation on BYDV-PAV incidence. This is the first demonstration that soil microbes can mediate the effects of $\mathrm{N}$ supply on a non-soilborne plant pathogen. Of the three general mechanisms through which soil microbes can affect plant-pathogen interactionsmodified access to resources (Schimel \& Bennett, 2004; van der Heijden et al., 2008; Kuzyakov $\& \mathrm{Xu}, 2013$ ), interference with pathogens in the soil (Lugtenberg \& Kamilova, 2009; Berendsen et al., 2012; Schlatter et al., 2017), and induced plant defenses (van Loon et al., 1998; Pieterse et al., 2014; Mauch-Mani et al., 2017) — the third is the most likely to apply to our study. Soil microbes did not significantly affect plant biomass and only affected leaf chlorophyll content in one treatment, suggesting that soil microbes did not generally affect plant access to resources. Because BYDV-PAV and CYDV-RPV are obligately transmitted to plants by aphid vectors (D’Arcy \& Burnett, 1995), soil microbes could only affect virus incidence indirectly via effects on the plant, ruling out the second mechanism. Induction of plant defenses could explain why BYDV-PAV incidence was significantly lower when plants were grown with microbes from low $\mathrm{N}$ soils. Further, ambient and low $\mathrm{N}$ microbes negated the effects of co-inoculation and $\mathrm{N}$ supply on BYDV-PAV incidence and the combined effect of co-inoculation and N supply on BYDVPAV incidence were sub-additive. These interactions are consistent with these factors affecting BYDV-PAV incidence through a common mechanism, such as host defenses.

Furthermore, increased N supply reduced BYDV-PAV incidence in singly inoculated plants grown in sterile soil. Higher $\mathrm{N}$ availability may have decreased plant susceptibility to 
infection, which has been demonstrated for other, usually necrotrophic, pathogens (Dordas, 2009; Vega et al., 2015). In a field experiment, N supply decreased BYDV-PAV incidence only when P supply was high, which suggests that the stoichiometry of nutrient supply (e.g., N:P) influences plant-pathogen interactions rather than the absolute supply (Borer et al., 2014). Our results may therefore indicate that BYDV-PAV infection was more successful when plants were grown with higher $\mathrm{P}: \mathrm{N}$ supply, perhaps due to higher within-host virus replication, as has been demonstrated in aquatic systems with P:C stoichiometry (Clasen \& Elser, 2007; Frost et al., 2008). However, studies that have measured within-host BYDV-PAV titer have not found a positive effect of P or P:N (Rúa et al., 2013; Whitaker et al., 2015; Lacroix et al., 2017; Kendig et al., 2020). The mechanism behind reduced BYDV-PAV incidence with higher $\mathrm{N}$ supply therefore requires a closer examination of plant defenses, within-host dynamics, and plant-vector interactions. Nitrogen supply no longer reduced infection incidence when plants were coinoculated. Interestingly, $\mathrm{N}$ supply and co-inoculation also interacted to affect virus incidence in a study conducted by Lacroix et. al. (2014), except that the interaction affected CYDV-RPV incidence rather than BYDV-PAV. These results suggest that BYDV-PAV and CYDV-RPV may interact within hosts and that nutrient supply may modify their interactions, analogous to pathogens in animal and human systems (Smith \& Holt, 1996; Smith, 2014).

The long-term, field fertilization treatments that shaped the soil microbial communities modified plant-microbe and plant-pathogen interactions. Only soil microbes exposed to multiple decades of low $\mathrm{N}$ fertilization affected BYDV-PAV incidence in singly inoculated plants. In addition, co-inoculation only reduced BYDV-PAV incidence in plants grown with sterile soil or microbes from long-term high $\mathrm{N}$ fertilization conditions. If soil microbes affected BYDV-PAV incidence through induced plant defenses, these results suggest that the long-term $\mathrm{N}$ enrichment could indirectly influence plant defenses via the soil microbial community. Specifically, microbes that have experienced lower long-term $\mathrm{N}$ fertilization tended to reduce BYDV-PAV incidence more than microbes that experienced long-term high $\mathrm{N}$ fertilization. This result contrasts with previous studies that have demonstrated that higher nutrient availability increased the disease suppressive activity of plant-associated microbes (Wiggins \& Kinkel, 2005; Berg \& Koskella, 2018). We also found that BYDV-PAV infection only reduced leaf chlorophyll content when plants were grown with microbes exposed to long-term ambient N. This result suggests that not only can the microbial community mediate the success of BYDV-PAV infection, but it 
also can mediate some of the symptoms of infection experienced by plants. We do not know whether long-term $\mathrm{N}$ fertilization shifted the composition or function of the soil microbial communities (Leff et al., 2015; Klinger et al., 2016; Chen et al., 2019), but subsequent studies could characterize microbial taxa and function associated with changes in BYDV-PAV infection.

We selected the host species and virus species because of their importance for agriculture (Mckirdy et al., 2002; Riedell et al., 2007) and the wide knowledge base provided by previous studies (Carrigan et al., 1983; Baltenberger et al., 1987; Power et al., 1991; Erion \& Riedell, 2012; Lacroix et al., 2014). However, the host species does not naturally co-occur with the soil microbial communities sampled in this study, which may have limited the observed effects of microbe inoculum on plant growth and plant-pathogen interactions (Essarioui et al., 2020). Indeed, studies that have used co-occurring plant species and soil microbial communities have found statistically significant effects of the $\mathrm{N}$ fertilization history of microbes on plant biomass (Johnson, 1993; Weese et al., 2015). Therefore, our study may have isolated the effects of soil microbes that are generalists or that affect plant-pathogen interactions without requiring coevolved interactions. A follow-up study may consider exploring the relationship of nutrients, plant pathogens, and soil microbes from communities in which the species naturally occur. In addition to no effect of soil microbes on plant biomass, we also found no effect of infection on plant biomass. BYDV-PAV and CYDV-RPV infections typically reduce plant biomass (Baltenberger et al., 1987; Erion \& Riedell, 2012), but the effects of plant pathogens are highly dependent on environmental conditions (Barrett et al., 2009). Additionally, based on simulated datasets, our results demonstrated that our study's sample sizes may have impeded our ability to detect small changes in biomass.

Barley and Cereal Yellow Dwarf Viruses are vectored by aphids, which may mediate the effects of soil nutrients and soil microbes on plant-pathogen and pathogen-pathogen interactions. For example, increasing $\mathrm{N}$ supply to plants can increase or decrease the length of time that aphids feed (Nowak \& Komor, 2010; Bogaert et al., 2017), which affects the probability that viruses successfully infect plants (Power et al., 1991). Soil microbial communities can also influence the feeding behavior and population dynamics of aphids (Pineda et al., 2010). For example, soil microbes can increase or decrease the weight, body size, and intrinsic growth rate of aphids (Hol et al., 2010; Pineda et al., 2012; Hackett et al., 2013). Higher aphid population densities may increase the co-infection incidence of B/CYDVs (Seabloom et 
al., 2009). In addition, $\mathrm{N}$ supply and soil microbial communities may interact to affect aphid vectors because the effects of microbes on insect herbivores tend to be stronger when plants experience abiotic stress (Pineda et al., 2013). For instance, a previous study demonstrated that other soil-dwelling organisms, nematodes, affected aphid population growth rates and plant preference only when $\mathrm{N}$ was limited (Kutyniok et al., 2014). To evaluate the role of aphids in pathogen responses to $\mathrm{N}$ supply and soil microbial communities, future studies could investigate the effects of $\mathrm{N}$ and microbes on aphid feeding duration in the lab and aphid population dynamics in the field.

Our experiment provided a first demonstration that soil microbes can affect the incidence of an insect-vectored virus, BYDV-PAV, in a plant host, A. sativa. Because soil microbes mediated the effects of contemporary $\mathrm{N}$ supply, and the $\mathrm{N}$ fertilization history of soil microbes impacted both incidence and chlorophyll of infected plants, our results suggest that inferences about how $\mathrm{N}$ enrichment modifies plant pathogens based on laboratory experiments will depend on the role of soil microbes. Further, our results suggest that high $\mathrm{N}$ fertilization could reduce the pathogen suppressive effects of soil microbes for some plant-pathogen pairs, potentially leading to more widespread infection under field conditions with elevated $\mathrm{N}$ supply. This work demonstrates the important indirect role of soil microbial communities for infection outcomes, pointing to an exciting new frontier: examining the generality and context-dependence of these results, and the indirect role of soil microbes in the high variation in plant-microbe (Smith \& Goodman, 1999) and plant-pathogen (Hoffland et al., 2000) interactions.

\section{Acknowledgements}

This work was supported by the NSF program in Ecology and Evolution of Infectious Diseases (grant DEB-1015805). This work also was supported by grants from the US National Science Foundation Long-Term Ecological Research Program (LTER) including DEB-1234162 and DEB-1831944. Further support was provided by the Cedar Creek Ecosystem Science Reserve, the Minnesota Supercomputer Institute, and the University of Minnesota.

\section{Author Contribution}


All authors contributed to the design of the research, CE performed the research and data collection, CAE and AEK performed the data analysis and wrote the first draft of the manuscript, and all authors contributed to manuscript revisions.

\section{Data Availability}

Data will be accessible through the Environmental Data Initiative upon manuscript publication.

\section{References}

Baltenberger DE, Ohm HW, Foster JE. 1987. Reactions of oat, barley, and wheat to infection with barley yellow dwarf virus isolates. Crop Science 27: 195-198.

Barrett LG, Kniskern JM, Bodenhausen N, Zhang W, Bergelson J. 2009. Continua of specificity and virulence in plant host-pathogen interactions: Causes and consequences. New Phytologist 183: 513-529.

Bass D, Stentiford GD, Wang H-C, Koskella B, Tyler CR. 2019. The pathobiome in animal and plant diseases. Trends in Ecology \& Evolution 34: 996-1008.

Bellin D, Asai S, Delledonne M, Yoshioka H. 2013. Nitric oxide as a mediator for defense responses. Molecular Plant-Microbe Interactions 26: 271-7.

Berendsen RL, Pieterse CMJ, Bakker PAHM. 2012. The rhizosphere microbiome and plant health. Trends in Plant Science 17: 478-486.

Berg M, Koskella B. 2018. Nutrient- and dose-dependent microbiome-mediated protection against a plant pathogen. Current Biology 28: 2487-2492.

Bogaert F, Chesnais Q, Catterou M, Rambaud C, Doury G, Ameline A. 2017. How the use of nitrogen fertiliser may switch plant suitability for aphids: the case of Miscanthus, a promising biomass crop, and the aphid pest Rhopalosiphum maidis. Pest Management Science 73: 16481654.

\section{Borer ET, Asik L, Everett RA, Frenken T, Gonzalez AL, Paseka RE, Peace A, Seabloom}

EW, Strauss AT, Van de Waal DB, et al. 2021. Elements of disease in a changing world: modelling feedbacks between infectious disease and ecosystems. Ecology Letters 24: 6-19. Borer ET, Seabloom EW, Mitchell CE, Cronin JP. 2014. Multiple nutrients and herbivores interact to govern diversity, productivity, composition, and infection in a successional grassland. Oikos 123: 214-224. 
Bürkner P-C. 2017. brms: An R package for Bayesian multilevel models using Stan. Journal of Statistical Software 80: 1-28.

Carrigan LL, Ohm HW, Foster JE. 1983. Barley yellow dwarf virus translocation in wheat and oats. Crop Science 23: 611-612.

Chen D, Xing W, Lan Z, Saleem M, Wu Y, Hu S, Bai Y. 2019. Direct and indirect effects of nitrogen enrichment on soil organisms and carbon and nitrogen mineralization in a semi-arid grassland. Functional Ecology 33: 175-187.

Clark CM, Tilman D. 2008. Loss of plant species after chronic low-level nitrogen deposition to prairie grasslands. Nature 451: 712-5.

Clasen JL, Elser JJ. 2007. The effect of host Chlorella NC64A carbon:phosphorus ratio on the production of Paramecium bursaria Chlorella Virus-1. Freshwater Biology 52: 112-122.

D’Arcy CJ, Burnett PA. 1995. Barley Yellow Dwarf: 40 Years of Progress. St. Paul, MN, USA: The American Phytopathological Society.

Deb M, Anderson JM. 2008. Development of a multiplexed PCR detection method for Barley and Cereal yellow dwarf viruses, Wheat spindle streak virus, Wheat streak mosaic virus and Soil-borne wheat mosaic virus. Journal of Virological Methods 148: 17-24.

Dietrich R, Ploß K, Heil M. 2004. Constitutive and induced resistance to pathogens in Arabidopsis thaliana depend on nitrogen supply. Plant, Cell \& Environment 27: 896-906.

Dordas C. 2009. Role of Nutrients in Controlling Plant Diseases in Sustainable Agriculture: A Review. In: Lichtfouse E, Navarrete M, Debaeke P, Véronique S, Alberola C, eds. Sustainable Agriculture. Dordrecht, Netherlands: Springer, 443-460.

Elser JJ, Bracken MES, Cleland EE, Gruner DS, Harpole WS, Hillebrand H, Ngai JT, Seabloom EW, Shurin JB, Smith JE. 2007. Global analysis of nitrogen and phosphorus limitation of primary producers in freshwater, marine and terrestrial ecosystems. Ecology Letters 10: $1135-1142$.

Erion GG, Riedell WE. 2012. Barley Yellow Dwarf Virus effects on cereal plant growth and transpiration. Crop Science 52: 2794.

Essarioui A, LeBlanc N, Otto-Hanson L, Schlatter DC, Kistler HC, Kinkel LL. 2020.

Inhibitory and nutrient use phenotypes among coexisting Fusarium and Streptomyces populations suggest local coevolutionary interactions in soil. Environmental Microbiology 22: 976-985. 
Fagard M, Launay A, Clement G, Courtial J, Dellagi A, Farjad M, Krapp A, Soulie M-C, Masclaux-Daubresse C. 2014. Nitrogen metabolism meets phytopathology. Journal of Experimental Botany 65: 5643-5656.

Farrer EC, Suding KN. 2016. Teasing apart plant community responses to N enrichment: the roles of resource limitation, competition and soil microbes. Ecology Letters 19: 1287-1296.

Fierer N, Lauber CL, Ramirez KS, Zaneveld J, Bradford M a, Knight R. 2012. Comparative metagenomic, phylogenetic and physiological analyses of soil microbial communities across nitrogen gradients. The ISME Journal 6: 1007-17.

Frost PC, Ebert D, Smith VH. 2008. Responses of a bacterial pathogen to phosphorus limitation of its aquatic invertebrate host. Ecology 89: 313-318.

Galloway JN, Dentener FJ, Capone DG, Boyer EW, Howarth RW, Seitzinger SP, Asner GP, Cleveland CC, Green PA, Holland EA, et al. 2004. Nitrogen cycles: past, present, and future. Biogeochemistry 70: 153-226.

Hackett SC, Karley AJ, Bennett AE. 2013. Unpredicted impacts of insect endosymbionts on interactions between soil organisms, plants and aphids. Proceedings of the Royal Society B: Biological Sciences $\mathbf{2 8 0}$.

He Q, Silliman BR. 2015. Biogeographic consequences of nutrient enrichment for plantherbivore interactions in coastal wetlands. Ecology Letters 18: 462-471.

van der Heijden MGA, Bardgett RD, van Straalen NM. 2008. The unseen majority: soil microbes as drivers of plant diversity and productivity in terrestrial ecosystems. Ecology Letters 11: $296-310$.

Hoagland DR, Arnon DI. 1938. The water culture method for growing plants without soil. California Agricultural Experiment Station Circular 347: 32.

Hoffland E, Jeger MJ, van Beusichem ML. 2000. Effect of nitrogen supply rate on disease resistance in tomato depends on the pathogen. Plant and Soil 218: 239-247.

Hol WHG, de Boer W, Termorshuizen AJ, Meyer KM, Schneider JHM, van Dam NM, van Veen JA, van der Putten WH. 2010. Reduction of rare soil microbes modifies plant-herbivore interactions. Ecology Letters 13: 292-301.

Huang R, McGrath SP, Hirsch PR, Clark IM, Storkey J, Wu L, Zhou J, Liang Y. 2019. Plant-microbe networks in soil are weakened by century-long use of inorganic fertilizers. Microbial Biotechnology 12: 1464-1475. 
Irwin ME, Thresh JM. 1990. Epidemiology of barley yellow dwarf: A study in ccological complexity. Annual Review of Phytopathology 28: 393-424.

Isbell F, Reich PB, Tilman D, Hobbie SE, Polasky S, Binder S. 2013a. Nutrient enrichment, biodiversity loss, and consequent declines in ecosystem productivity. Proceedings of the National Academy of Sciences of the United States of America 110: 11911-11916.

Isbell F, Tilman D, Polasky S, Binder S, Hawthorne P. 2013b. Low biodiversity state persists two decades after cessation of nutrient enrichment. Ecology Letters 16: 454-460.

Jia X, Zhong Y, Liu J, Zhu G, Shangguan Z, Yan W. 2020. Effects of nitrogen enrichment on soil microbial characteristics: From biomass to enzyme activities. Geoderma 366.

Johnson NC. 1993. Can fertilization of soil select less mutualistic mycorrhizae. Ecological Applications 3: 749-757.

Keeler BL, Hobbie SE, Kellogg LE. 2008. Effects of long-term nitrogen addition on microbial enzyme activity in eight forested and grassland sites: Implications for litter and soil organic matter decomposition. Ecosystems 12: 1-15.

Kendig AE, Borer ET, Boak EN, Picard TC, Seabloom EW. 2020. Host nutrition mediates interactions between plant viruses, altering transmission and predicted disease spread. Ecology $\mathbf{0}$ : 1-12.

Klinger CR, Lau JA, Heath KD. 2016. Ecological genomics of mutualism decline in nitrogenfixing bacteria. Proceedings of the Royal Society B: Biological Sciences 283.

Kurz AS. 2019. Bayesian power analysis: Part I. Prepare to reject HO with simulation. [WWW document] URL https://solomonkurz.netlify.app/post/bayesian-power-analysis-part-i/. [accessed 19 April 2021].

Kutyniok M, Persicke M, Müller C. 2014. Effects of root herbivory by nematodes on the performance and preference of a leaf-infesting generalist aphid depend on nitrate fertilization. Journal of Chemical Ecology 40: 118-127.

Kuzyakov Y, Xu X. 2013. Competition between roots and microorganisms for nitrogen:

Mechanisms and ecological relevance. New Phytologist 198: 656-669.

Lacroix C, Seabloom EW, Borer ET. 2014. Environmental nutrient supply alters prevalence and weakens competitive interactions among coinfecting viruses. The New Phytologist 204: 424433.

Lacroix C, Seabloom EW, Borer ET. 2017. Environmental nutrient supply directly alters plant 
traits but indirectly determines virus growth rate. Frontiers in Microbiology 8: 2116.

Leff JW, Jones SE, Prober SM, Barberán A, Borer ET, Firn JL, Harpole WS, Hobbie SE, Hofmockel KS, Knops JMH, et al. 2015. Consistent responses of soil microbial communities to elevated nutrient inputs in grasslands across the globe. Proceedings of the National Academy of Sciences of the United States of America 112: 10967-72.

van Loon LC, Bakker PAHM, Pieterse CMJ. 1998. Systemic resistance induced by rhizosphere bacteria. Annual Review of Phytopathology 36: 453-483.

Lovett GM, Arthur MA, Weathers KC, Griffin JM. 2010. Long-term changes in forest carbon and nitrogen cycling caused by an introduced pest/pathogen complex. Ecosystems 13: 1188-1200.

Lugtenberg B, Kamilova F. 2009. Plant-growth-promoting rhizobacteria. Annual Review of Microbiology 63: 541-556.

Mauch-Mani B, Baccelli I, Luna E, Flors V. 2017. Defense priming: An adaptive part of induced resistance. Annual Review of Plant Biology 68: 485-512.

McElreath R. 2015. Statistical Rethinking. Boca Raton, FL, USA: Taylor \& Francis Group.

Mckirdy SJ, Jones RAC, Section PP, No LB, Nutter FW, Pathology P, Hall B, Uni- IS.

2002. Quantification of Yield Losses Caused by Barley yellow dwarf virus in Wheat and Oats.

Plant Disease 86: 769-773.

Midolo G, Alkemade R, Schipper AM, Benítez-López A, Perring MP, De Vries W. 2019.

Impacts of nitrogen addition on plant species richness and abundance: A global meta-analysis. Global Ecology and Biogeography 28: 398-413.

Miller W a, Liu SJ, Beckett R. 2002. Barley yellow dwarf virus: Luteoviridae or Tombusviridae? Molecular Plant Pathology 3: 177-183.

Mitchell CE, Reich PB, Tilman D, Groth J V. 2003. Effects of elevated CO2, nitrogen deposition, and decreased species diversity on foliar fungal plant disease. Global Change Biology 9: 438-451.

Moreau D, Pivato B, Bru D, Busset H, Deau F, Faivre C, Matejicek A, Strbik F, Philippot L, Mougel C. 2015. Plant traits related to nitrogen uptake influence plant-microbe competition. Ecology 96: 2300-2310.

Mueller KE, Hobbie SE, Tilman D, Reich PB. 2013. Effects of plant diversity, N fertilization, and elevated carbon dioxide on grassland soil N cycling in a long-term experiment. Global 
Change Biology 19: 1249-1261.

Mur LAJ, Simpson C, Kumari A, Gupta AK, Gupta KJ. 2016. Moving nitrogen to the centre of plant defence against pathogens. Annals of Botany: 1-7.

Nowak H, Komor E. 2010. How aphids decide what is good for them: experiments to test aphid feeding behaviour on Tanacetum vulgare (L.) using different nitrogen regimes. Oecologia 163: 973-984.

Otto-Hanson LK, Grabau Z, Rosen C, Salomon CE, Kinkel LL. 2013. Pathogen variation and urea influence selection and success of Streptomyces mixtures in biological control. Phytopathology 103: 34-42.

Paseka RE, White LA, Van de Waal DB, Strauss AT, González AL, Everett RA, Peace A, Seabloom EW, Frenken T, Borer ET. 2020. Disease-mediated ecosystem services: Pathogens, plants, and people. Trends in Ecology and Evolution 35: 731-743.

Pieterse CMJ, Zamioudis C, Berendsen RL, Weller DM, Van Wees SCM, Bakker PAHM. 2014. Induced systemic resistance by beneficial microbes. Annual Review of Phytopathology $\mathbf{5 2}$ : 347-75.

Pineda A, Dicke M, Pieterse CMJ, Pozo MJ. 2013. Beneficial microbes in a changing environment: Are they always helping plants to deal with insects? Functional Ecology 27: 574586.

Pineda A, Zheng SJ, van Loon JJA, Dicke M. 2012. Rhizobacteria modify plant-aphid interactions: A case of induced systemic susceptibility. Plant Biology 14: 83-90.

Pineda A, Zheng SJ, van Loon JJA, Pieterse CMJ, Dicke M. 2010. Helping plants to deal with insects: The role of beneficial soil-borne microbes. Trends in Plant Science 15: 507-514. Power A, Seaman A, Gray S. 1991. Aphid transmission of barley yellow dwarf virus: Inoculation access periods and epidemiological implications. Phytopathology 81: 545-548. R Core Team. 2020. $R$ : A language and environment for statistical computing. Vienna, Austria: R Foundation for Statistical Computing.

Ramirez KS, Craine JM, Fierer N. 2012. Consistent effects of nitrogen amendments on soil microbial communities and processes across biomes. Global Change Biology 18: 1918-1927. Riedell WE, Osborne SL, Jaradat AA. 2007. Crop mineral nutrient and yield responses to aphids or barley yellow dwarf virus in spring wheat and oat. Crop Science 47: 1553-1560.

Ritchie ME. 2000. Nitrogen limitation and trophic vs. abiotic influences on insect herbivores in 
a temperate grassland. Ecology 81: 1601-1612.

Robert C, Bancal M-O, Lannou C. 2004. Wheat leaf rust uredospore production on adult plants: Influence of leaf nitrogen content and Septoria tritici blotch. Phytopathology 94: 712-21.

Rúa MA, Umbanhowar J, Hu S, Burkey KO, Mitchell CE. 2013. Elevated CO2 spurs reciprocal positive effects between a plant virus and an arbuscular mycorrhizal fungus. New Phytologist 199: 541-549.

Schimel JP, Bennett J. 2004. Nitrogen mineralization: Challenges of a changing paradigm. Ecology 85: 591-602.

Schlatter DC, DavelosBaines AL, Xiao K, Kinkel LL. 2013. Resource use of soilborne Streptomyces varies with location, phylogeny, and nitrogen amendment. Microbial Ecology 66: 961-971.

Schlatter D, Kinkel L, Thomashow L, Weller D, Paulitz T. 2017. Disease suppressive soils: New insights from the soil microbiome. Phytopathology 107: 1284-1297.

Seabloom EW, Borer ET, Mitchell CE, Power AG. 2010. Viral diversity and prevalence gradients in North American Pacific Coast grasslands. Ecology 91: 721-732.

Seabloom EW, Hosseini PR, Power AG, Borer ET. 2009. Diversity and composition of viral communities: Coinfection of barley and cereal yellow dwarf viruses in California grasslands. The American Naturalist 173: E79-E98.

Sedlacek JD, Barrett GW, Shaw DR. 1988. Effects of nutrient enrichment on the Auchenorrhyncha (Homoptera) in contrasting grassland communities. The Journal of Applied Ecology 25: 537.

Singh R. 1970. Influence of nitrogen supply on host susceptibiliy to tobacco mosaic virus infection. Phyton-Annales Rei Botanicae 14: 37-39.

Smith V. 2014. Nutrient supply differentially alters the dynamics of co-infecting phytoviruses. New Phytologist 204: 265-267.

Smith KP, Goodman RM. 1999. Host variation for interactions with beneficial plant-associated microbes. Annual Review of Phytopathology 37: 473-491.

Smith VH, Holt RD. 1996. Resource competition and within-host disease dynamics. Trends in Ecology \& Evolution 11: 386-389.

Sterner RW, Elser JJ. 2002. Ecological Stoichiometry: The Biology of Elements from Molecules to the Biosphere. Princeton, NJ, USA: Princeton University Press. 
Tilman D. 1987. Secondary succession and the pattern of plant dominance along experimental nitrogen gradients. Ecological Monographs 57: 189-214.

Treseder KK. 2004. A meta-analysis of mycorrhizal responses to nitrogen, phosphorus, and atmospheric CO2 in field studies. New Phytologist 164: 347-355.

Vega A, Canessa P, Hoppe G, Retamal I, Moyano TC, Canales J, Gutiérrez RA, Rubilar J. 2015. Transcriptome analysis reveals regulatory networks underlying differential susceptibility to Botrytis cinerea in response to nitrogen availability in Solanum lycopersicum. Frontiers in Plant Science 6: 911.

Veresoglou SD, Barto EK, Menexes G, Rillig MC. 2013. Fertilization affects severity of disease caused by fungal plant pathogens. Plant Pathology 62: 961-969.

Vitousek PM, Aber JD, Howarth RW, Likens GE, Matson PA, Schindler DW, Schlesinger

WH, Tilman DG. 1997. Human alteration of the global nitrogen cycle: sources and consequences. Ecological Applications 7: 737-750.

Weese DJ, Heath KD, Dentinger BTM, Lau JA. 2015. Long-term nitrogen addition causes the evolution of less-cooperative mutualists. Evolution 69: 631-642.

Welch RW, Leggett JM. 1997. Nitrogen content, oil content and oil composition of oat cultivars (A. sativa) and wild Avena species in relation to nitrogen fertility, yield and partitioning of assimilates. Journal of Cereal Science 26: 105-120.

Whitaker BK, Rúa MA, Mitchell CE. 2015. Viral pathogen production in a wild grass host driven by host growth and soil nitrogen. New Phytologist 207: 760-768.

Wiggins BE, Kinkel LL. 2005. Green manures and crop sequences influence potato diseases and pathogen inhibitory activity of indigenous streptomycetes. Phytopathology 95: 178-185. Yang FY, Li GZ, Zhang DE, Christie P, Li XL, Gai JP. 2010. Geographical and plant genotype effects on the formation of arbuscular mycorrhiza in Avena sativa and Avena nuda at different soil depths. Biology and Fertility of Soils 46: 435-443.

Zhao B, Ma BL, Hu Y, Liu J. 2015. Characterization of nitrogen and water status in oat leaves using optical sensing approach. Journal of the Science of Food and Agriculture 95: 367-378. 


\section{Tables}

Table 1. Generalized linear model summary of BYDV-PAV incidence $(n=139)$.

\begin{tabular}{lccccc}
\hline & & \multicolumn{3}{c}{$\mathbf{9 5 \%}$ CI } \\
Variable & Estimate & Std. Error & Lower & Upper & Rhat \\
\hline intercept $^{\mathbf{b}}$ & $\mathbf{4 . 1 2}$ & $\mathbf{1 . 7 3}$ & $\mathbf{1 . 3 6}$ & $\mathbf{8 . 0 4}$ & $\mathbf{1 . 0 0}$ \\
N supply & $\mathbf{- 3 . 6 0}$ & $\mathbf{1 . 8 5}$ & $\mathbf{- 7 . 6 6}$ & $\mathbf{- 0 . 4 3}$ & $\mathbf{1 . 0 0}$ \\
co-inoculation & $\mathbf{- 4 . 9 5}$ & $\mathbf{1 . 8 2}$ & $\mathbf{- 8 . 9 7}$ & $\mathbf{- 1 . 9 2}$ & $\mathbf{1 . 0 0}$ \\
soil ambient N & -2.96 & 1.90 & -7.09 & 0.43 & 1.00 \\
soil low N & $\mathbf{- 4 . 2 7}$ & $\mathbf{1 . 8 4}$ & $\mathbf{- 8 . 3 7}$ & $\mathbf{- 1 . 2 0}$ & $\mathbf{1 . 0 0}$ \\
soil high N & 6.48 & 4.99 & -1.67 & 17.51 & 1.00 \\
N supply x co-inoculation & $\mathbf{3 . 9 2}$ & $\mathbf{2 . 0 1}$ & $\mathbf{0 . 3 4}$ & $\mathbf{8 . 1 9}$ & $\mathbf{1 . 0 0}$ \\
soil ambient N x N supply & 2.09 & 2.14 & -1.93 & 6.48 & 1.00 \\
soil low N x N supply & $\mathbf{5 . 8 4}$ & $\mathbf{2 . 2 4}$ & $\mathbf{1 . 8 8}$ & $\mathbf{1 0 . 6 4}$ & $\mathbf{1 . 0 0}$ \\
soil high N x N supply & 3.53 & 5.62 & -6.95 & 15.09 & 1.00 \\
soil ambient N x co-inoculation & $\mathbf{3 . 7 7}$ & $\mathbf{2 . 0 6}$ & $\mathbf{0 . 0 2}$ & $\mathbf{8 . 1 3}$ & $\mathbf{1 . 0 0}$ \\
soil low N x co-inoculation & $\mathbf{5 . 0 5}$ & $\mathbf{2 . 0 2}$ & $\mathbf{1 . 4 3}$ & $\mathbf{9 . 4 0}$ & $\mathbf{1 . 0 0}$ \\
soil high N x co-inoculation & -4.70 & 5.02 & -15.72 & 3.66 & 1.00 \\
soil ambient N x N supply x co-inoculation & -0.78 & 2.50 & -5.87 & 3.95 & 1.00 \\
soil low N x N supply x co-inoculation & -4.48 & 2.59 & -9.75 & 0.42 & 1.00 \\
soil high N x N supply x co-inoculation & -3.34 & 5.68 & -15.05 & 7.19 & 1.00 \\
\hline
\end{tabular}

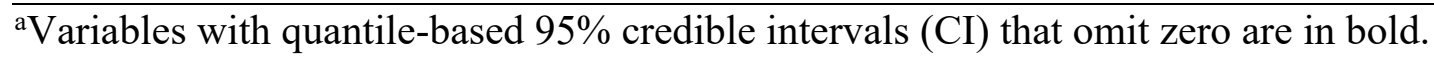

${ }^{b}$ Intercept factor levels: low $\mathrm{N}$ supply, single inoculation, sterile soil 
Table 2. Generalized linear model summary of CYDV-RPV incidence $(n=154)$.

\begin{tabular}{lccccc}
\hline & & \multicolumn{4}{c}{$\mathbf{9 5 \%}$ CI } \\
Variable & Estimate & Std. Error & Lower & Upper & Rhat \\
\hline intercept $^{\mathrm{b}}$ & 0.76 & 0.73 & -0.61 & 2.26 & 1.00 \\
N supply & 1.78 & 1.33 & -0.60 & 4.66 & 1.00 \\
co-inoculation & $\mathbf{- 3 . 2 7}$ & $\mathbf{1 . 3 1}$ & $\mathbf{- 6 . 1 5}$ & $\mathbf{- 0 . 9 4}$ & $\mathbf{1 . 0 0}$ \\
soil ambient N & 0.00 & 1.03 & -1.99 & 2.04 & 1.00 \\
soil low N & -0.49 & 1.01 & -2.48 & 1.45 & 1.00 \\
soil high N & -0.31 & 0.98 & -2.29 & 1.60 & 1.00 \\
N supply x co-inoculation & 0.72 & 1.78 & -2.84 & 4.18 & 1.00 \\
soil ambient N x N supply & -2.78 & 1.65 & -6.21 & 0.29 & 1.00 \\
soil low N x N supply & -1.29 & 1.66 & -4.71 & 1.85 & 1.00 \\
soil high N x N supply & -2.67 & 1.62 & -6.05 & 0.35 & 1.00 \\
soil ambient N x co-inoculation & 1.54 & 1.65 & -1.63 & 4.86 & 1.00 \\
soil low N x co-inoculation & 2.53 & 1.62 & -0.55 & 5.85 & 1.00 \\
soil high N x co-inoculation & 1.86 & 1.63 & -1.13 & 5.21 & 1.00 \\
soil ambient N x N supply x co-inoculation & 1.23 & 2.22 & -3.08 & 5.65 & 1.00 \\
soil low N x N supply x co-inoculation & -1.69 & 2.24 & -6.08 & 2.69 & 1.00 \\
soil high N x N supply x co-inoculation & 1.36 & 2.22 & -3.00 & 5.77 & 1.00 \\
\hline Variables with & & & & &
\end{tabular}

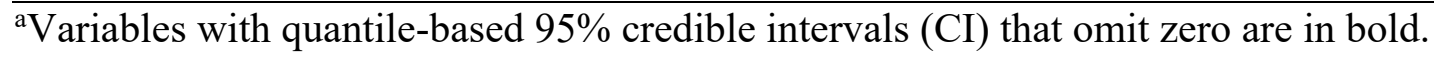

bintercept factor levels: low N supply, single inoculation, sterile soil 
Table 3. Generalized linear model summary of co-infection incidence $(n=79)$.

\begin{tabular}{lccccc}
\hline & & \multicolumn{4}{c}{$\mathbf{9 5 \%}$ CI } \\
Variable $^{\mathbf{a}}$ & Estimate & Std. Error & Lower & Upper & Rhat \\
\hline intercept $^{\mathbf{b}}$ & $\mathbf{- 2 . 6 0}$ & $\mathbf{1 . 1 6}$ & $\mathbf{- 5 . 2 3}$ & $\mathbf{- 0 . 7 2}$ & $\mathbf{1 . 0 0}$ \\
N supply & 1.01 & 1.42 & -1.67 & 3.94 & 1.00 \\
soil ambient N & -0.07 & 1.70 & -3.58 & 3.25 & 1.00 \\
soil low N & 0.99 & 1.45 & -1.70 & 4.04 & 1.00 \\
soil high N & 0.99 & 1.44 & -1.70 & 4.01 & 1.00 \\
soil ambient N x N supply & 1.65 & 1.99 & -2.12 & 5.71 & 1.00 \\
soil low N x N supply & -0.35 & 1.81 & -4.01 & 3.12 & 1.00 \\
soil high N x N supply & 0.34 & 1.79 & -3.24 & 3.73 & 1.00 \\
\hline
\end{tabular}

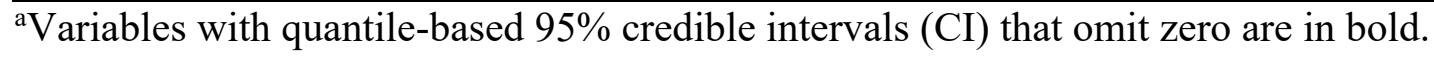

bIntercept factor levels: low N supply, sterile soil 
Table 4. Linear model summary of log-transformed aboveground biomass $(n=154)$.

\begin{tabular}{|c|c|c|c|c|c|}
\hline \multirow[b]{2}{*}{ Variable $^{a}$} & \multirow[b]{2}{*}{ Estimate } & \multirow[b]{2}{*}{ Std. Error } & \multicolumn{2}{|c|}{$95 \% \mathrm{CI}$} & \multirow[b]{2}{*}{ Rhat } \\
\hline & & & Lower & Upper & \\
\hline intercept $^{b}$ & -1.61 & 0.19 & -1.97 & -1.24 & 1.00 \\
\hline N supply & 0.61 & 0.25 & 0.11 & 1.11 & 1.00 \\
\hline BYDV-PAV infection & 0.19 & 0.26 & -0.31 & 0.69 & 1.00 \\
\hline CYDV-RPV infection & -0.23 & 0.28 & -0.79 & 0.32 & 1.00 \\
\hline soil ambient $\mathrm{N}$ & 0.03 & 0.30 & -0.56 & 0.62 & 1.00 \\
\hline soil low $\mathrm{N}$ & 0.51 & 0.26 & -0.01 & 1.02 & 1.00 \\
\hline soil high $\mathrm{N}$ & 0.09 & 0.27 & -0.45 & 0.62 & 1.00 \\
\hline N supply x BYDV-PAV & -0.13 & 0.41 & -0.93 & 0.66 & 1.00 \\
\hline N supply x CYDV-RPV & -0.06 & 0.37 & -0.79 & 0.68 & 1.00 \\
\hline soil ambient $\mathrm{N} x \mathrm{~N}$ supply & 0.25 & 0.39 & -0.52 & 1.00 & 1.00 \\
\hline soil low N x N supply & -0.22 & 0.37 & -0.94 & 0.51 & 1.00 \\
\hline soil high $\mathrm{N} x \mathrm{~N}$ supply & 0.14 & 0.37 & -0.58 & 0.85 & 1.00 \\
\hline soil ambient N x BYDV-PAV & -0.52 & 0.42 & -1.34 & 0.31 & 1.00 \\
\hline soil low N x BYDV-PAV & -0.41 & 0.41 & -1.22 & 0.42 & 1.00 \\
\hline soil high N x BYDV-PAV & 0.07 & 0.38 & -0.67 & 0.81 & 1.00 \\
\hline soil ambient N x CYDV-RPV & -0.30 & 0.42 & -1.13 & 0.53 & 1.00 \\
\hline soil low N x CYDV-RPV & -0.39 & 0.41 & -1.20 & 0.43 & 1.00 \\
\hline soil high N x CYDV-RPV & 0.12 & 0.41 & -0.68 & 0.93 & 1.00 \\
\hline soil ambient $\mathrm{N}$ x $\mathrm{N}$ supply x BYDV-PAV & 0.03 & 0.63 & -1.19 & 1.28 & 1.00 \\
\hline soil low N x N supply x BYDV-PAV & -0.19 & 0.59 & -1.35 & 0.95 & 1.00 \\
\hline soil high $\mathrm{N}$ x N supply x BYDV-PAV & -0.26 & 0.56 & -1.35 & 0.83 & 1.00 \\
\hline soil ambient $\mathrm{N}$ x $\mathrm{N}$ supply x CYDV-RPV & 0.19 & 0.58 & -0.93 & 1.34 & 1.00 \\
\hline soil low $\mathrm{N}$ x N supply x CYDV-RPV & 0.00 & 0.56 & -1.08 & 1.10 & 1.00 \\
\hline soil high $\mathrm{N} x \mathrm{~N}$ supply x CYDV-RPV & -0.67 & 0.57 & -1.79 & 0.44 & 1.00 \\
\hline
\end{tabular}

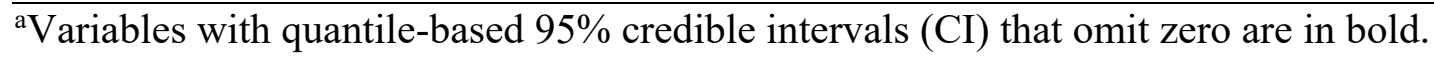

${ }^{b}$ Intercept factor levels: low N supply, mock inoculation, sterile soil 
Table 5. Linear model summary of log-transformed leaf chlorophyll content $(n=154)$.

\begin{tabular}{|c|c|c|c|c|c|}
\hline \multirow[b]{2}{*}{ Variable $^{a}$} & \multirow[b]{2}{*}{ Estimate } & \multicolumn{4}{|c|}{$95 \% \mathrm{CI}$} \\
\hline & & Std. Error & Lower & Upper & Rhat \\
\hline intercept $^{b}$ & 3.13 & 0.05 & 3.04 & 3.23 & 1.00 \\
\hline N supply & 0.17 & 0.07 & 0.04 & 0.30 & 1.00 \\
\hline BYDV-PAV infection & 0.08 & 0.07 & -0.05 & 0.21 & 1.00 \\
\hline CYDV-RPV infection & 0.06 & 0.07 & -0.09 & 0.20 & 1.00 \\
\hline soil ambient $\mathrm{N}$ & 0.05 & 0.08 & -0.11 & 0.20 & 1.00 \\
\hline soil low $\mathrm{N}$ & 0.00 & 0.07 & -0.14 & 0.14 & 1.00 \\
\hline soil high $\mathrm{N}$ & 0.02 & 0.07 & -0.13 & 0.16 & 1.00 \\
\hline N supply x BYDV-PAV & -0.20 & 0.11 & -0.41 & 0.01 & 1.00 \\
\hline N supply x CYDV-RPV & -0.15 & 0.10 & -0.34 & 0.05 & 1.00 \\
\hline soil ambient $\mathrm{N} x \mathrm{~N}$ supply & -0.05 & 0.10 & -0.24 & 0.16 & 1.00 \\
\hline soil low N x N supply & 0.04 & 0.09 & -0.14 & 0.23 & 1.00 \\
\hline soil high N x N supply & 0.04 & 0.10 & -0.15 & 0.23 & 1.00 \\
\hline soil ambient $N \times$ BYDV-PAV & -0.32 & 0.11 & -0.53 & -0.11 & 1.00 \\
\hline soil low N x BYDV-PAV & -0.14 & 0.11 & -0.35 & 0.07 & 1.00 \\
\hline soil high N x BYDV-PAV & -0.06 & 0.10 & -0.25 & 0.14 & 1.00 \\
\hline soil ambient $\mathrm{N} x \mathrm{CYDV}-\mathrm{RPV}$ & -0.11 & 0.11 & -0.32 & 0.11 & 1.00 \\
\hline soil low N x CYDV-RPV & -0.04 & 0.11 & -0.25 & 0.17 & 1.00 \\
\hline soil high N x CYDV-RPV & -0.04 & 0.11 & -0.24 & 0.17 & 1.00 \\
\hline soil ambient $N \times N$ supply $x$ BYDV-PAV & 0.37 & 0.16 & 0.05 & 0.69 & 1.00 \\
\hline soil low N x N supply x BYDV-PAV & 0.06 & 0.15 & -0.24 & 0.35 & 1.00 \\
\hline soil high N x N supply x BYDV-PAV & 0.03 & 0.15 & -0.25 & 0.32 & 1.00 \\
\hline soil ambient $\mathrm{N}$ x N supply x CYDV-RPV & 0.22 & 0.15 & -0.08 & 0.52 & 1.00 \\
\hline soil low $\mathrm{N}$ x $\mathrm{N}$ supply x CYDV-RPV & 0.11 & 0.14 & -0.17 & 0.39 & 1.00 \\
\hline soil high $\mathrm{N}$ x N supply x CYDV-RPV & 0.04 & 0.15 & -0.26 & 0.33 & 1.00 \\
\hline
\end{tabular}

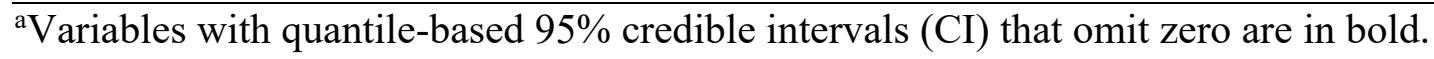

bIntercept factor levels: low N supply, mock inoculation, sterile soil 


\section{Figure Legends}

Figure 1. BYDV-PAV incidence (mean $\pm 95 \%$ confidence intervals) of plants grown with (a) sterile soil, (b) microbes exposed to long-term ambient $\mathrm{N}$, (c) microbes exposed to long-term low $\mathrm{N}$, and (d) microbes exposed to long-term high N. Plants were grown with low or high N supply and were either singly- or co-inoculated. Corresponding sample sizes are labelled under points and error bars.

Figure 2. CYDV-RPV incidence (mean $\pm 95 \%$ confidence intervals) of plants grown with (a) sterile soil, (b) microbes exposed to long-term ambient N, (c) microbes exposed to long-term low $\mathrm{N}$, and (d) microbes exposed to long-term high N. Plants were grown with low or high N supply and were either singly- or co-inoculated. Corresponding sample sizes are labelled under points and error bars.

Figure 3. Co-infection incidence (mean $\pm 95 \%$ confidence intervals) of plants grown with (a) sterile soil, (b) microbes exposed to long-term ambient N, (c) microbes exposed to long-term low $\mathrm{N}$, and (d) microbes exposed to long-term high N. Plants were grown with low or high N supply and all were co-inoculated. Corresponding sample sizes are labelled under points and error bars.

Figure 4. Biomass (g/plant, mean $\pm 95 \%$ confidence intervals) of plants grown with (a) sterile soil, (b) microbes exposed to long-term ambient $\mathrm{N}$, (c) microbes exposed to long-term low $\mathrm{N}$, and (d) microbes exposed to long-term high N. Plants were grown with low or high N supply and infected with mock inoculation, BYDV-PAV, CYDV-RPV, or both (co-infection).

Corresponding sample sizes are labelled under points and error bars.

Figure 5. Leaf chlorophyll content (SPAD, mean \pm 95\% confidence intervals) of plants grown with (a) sterile soil, (b) microbes exposed to long-term ambient $\mathrm{N}$, (c) microbes exposed to longterm low N, and (d) microbes exposed to long-term high N. Plants were grown with low or high $\mathrm{N}$ supply and infected with mock inoculation, BYDV-PAV, CYDV-RPV, or both (co-infection). Corresponding sample sizes are labelled under points and error bars. 
bioRxiv preprint doi: https://doi.org/10.1101/2021.04.28.441777; this version posted April 29, 2021. The copyright holder for this preprint (which was not certified by peer review) is the author/funder, who has granted bioRxiv a license to display the preprint in perpetuity. It is made available under aCC-BY-NC 4.0 International license.

\section{Figures}

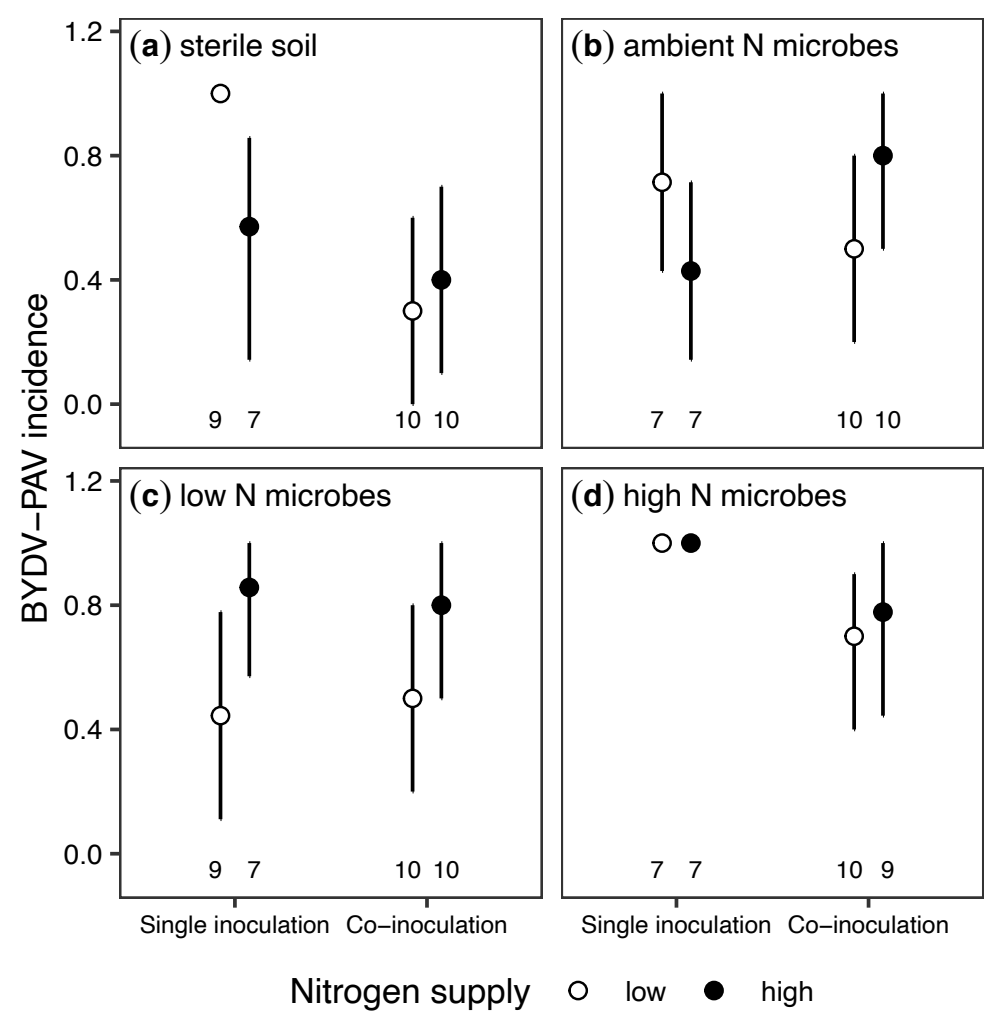

Fig. 1 
bioRxiv preprint doi: https://doi.org/10.1101/2021.04.28.441777; this version posted April 29, 2021. The copyright holder for this preprint (which

was not certified by peer review) is the author/funder, who has granted bioRxiv a license to display the preprint in perpetuity. It is made available under aCC-BY-NC 4.0 International license.
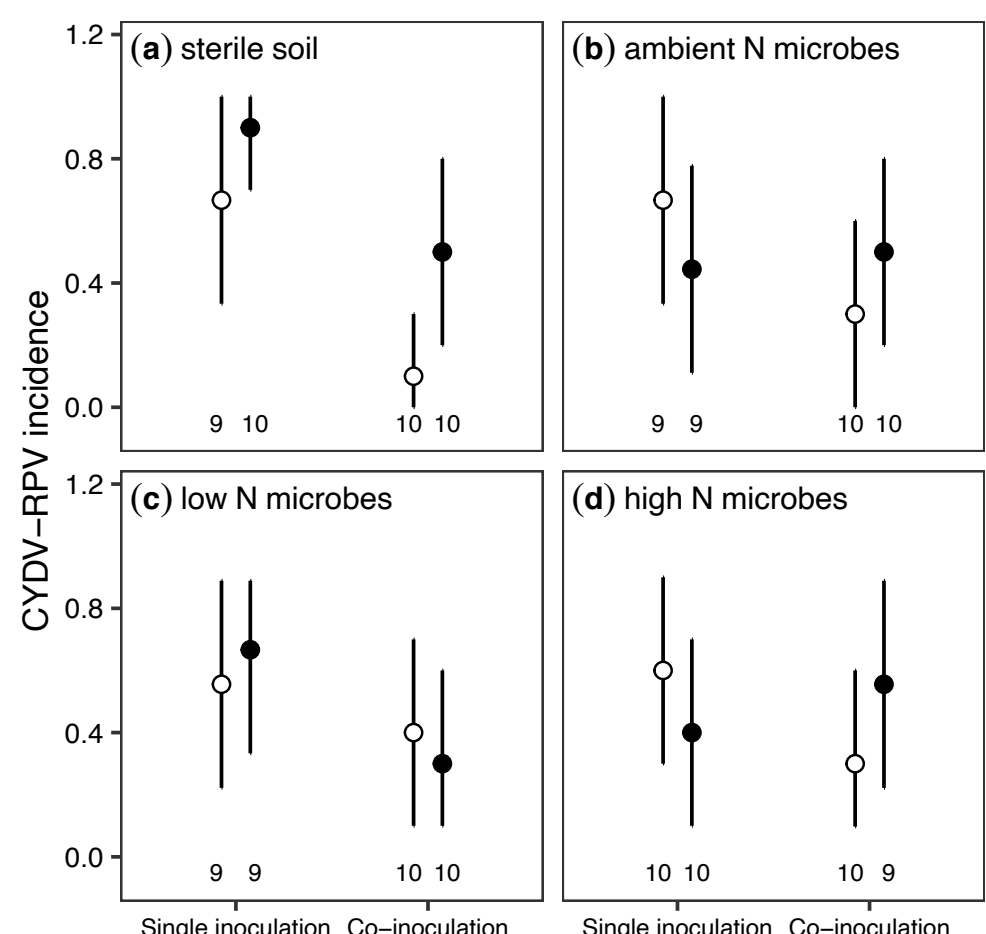

Nitrogen supply $\bigcirc$ low $\bullet$ high

Fig. 2 
bioRxiv preprint doi: https://doi.org/10.1101/2021.04.28.441777; this version posted April 29, 2021. The copyright holder for this preprint (which

was not certified by peer review) is the author/funder, who has granted bioRxiv a license to display the preprint in perpetuity. It is made available under aCC-BY-NC 4.0 International license.

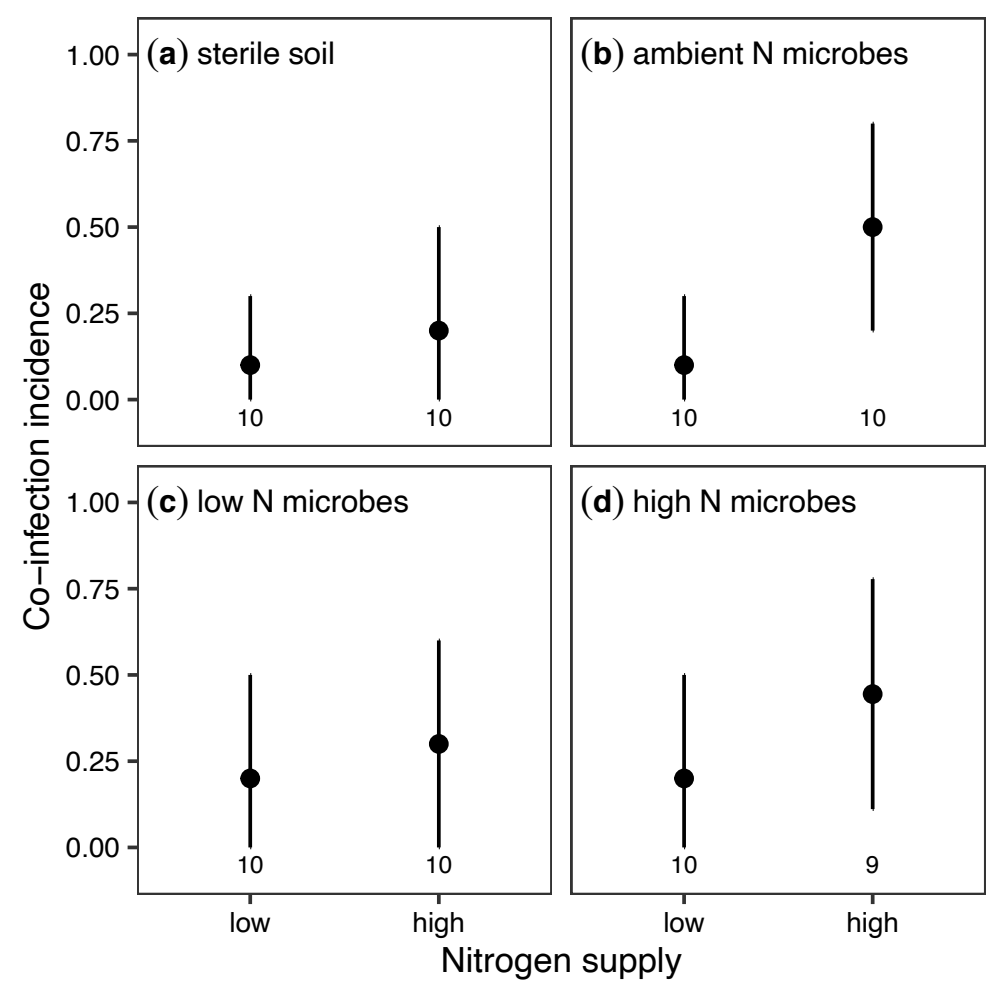

Fig. 3 
bioRxiv preprint doi: https://doi.org/10.1101/2021.04.28.441777; this version posted April 29, 2021. The copyright holder for this preprint (which

was not certified by peer review) is the author/funder, who has granted bioRxiv a license to display the preprint in perpetuity. It is made available under aCC-BY-NC 4.0 International license.

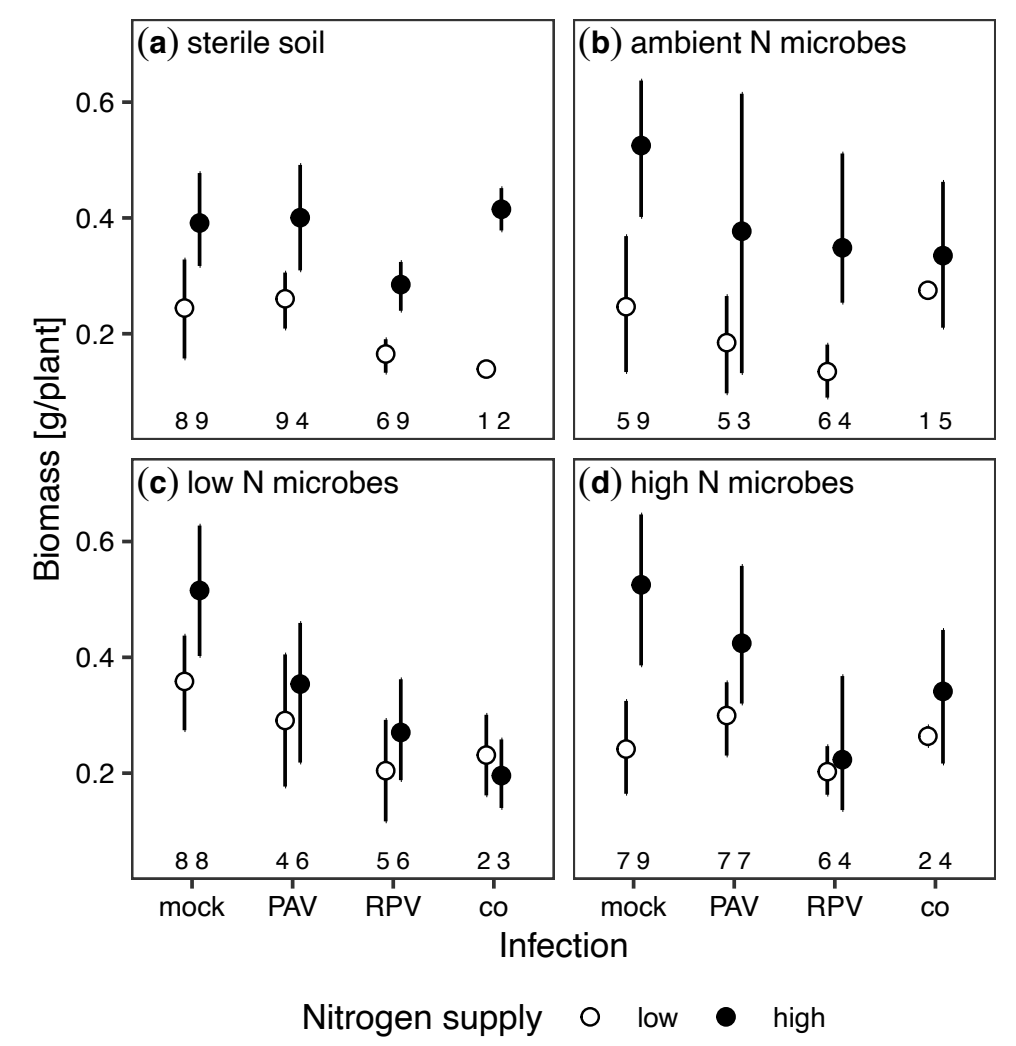

Fig. 4 
bioRxiv preprint doi: https://doi.org/10.1101/2021.04.28.441777; this version posted April 29, 2021. The copyright holder for this preprint (which

was not certified by peer review) is the author/funder, who has granted bioRxiv a license to display the preprint in perpetuity. It is made available under aCC-BY-NC 4.0 International license.

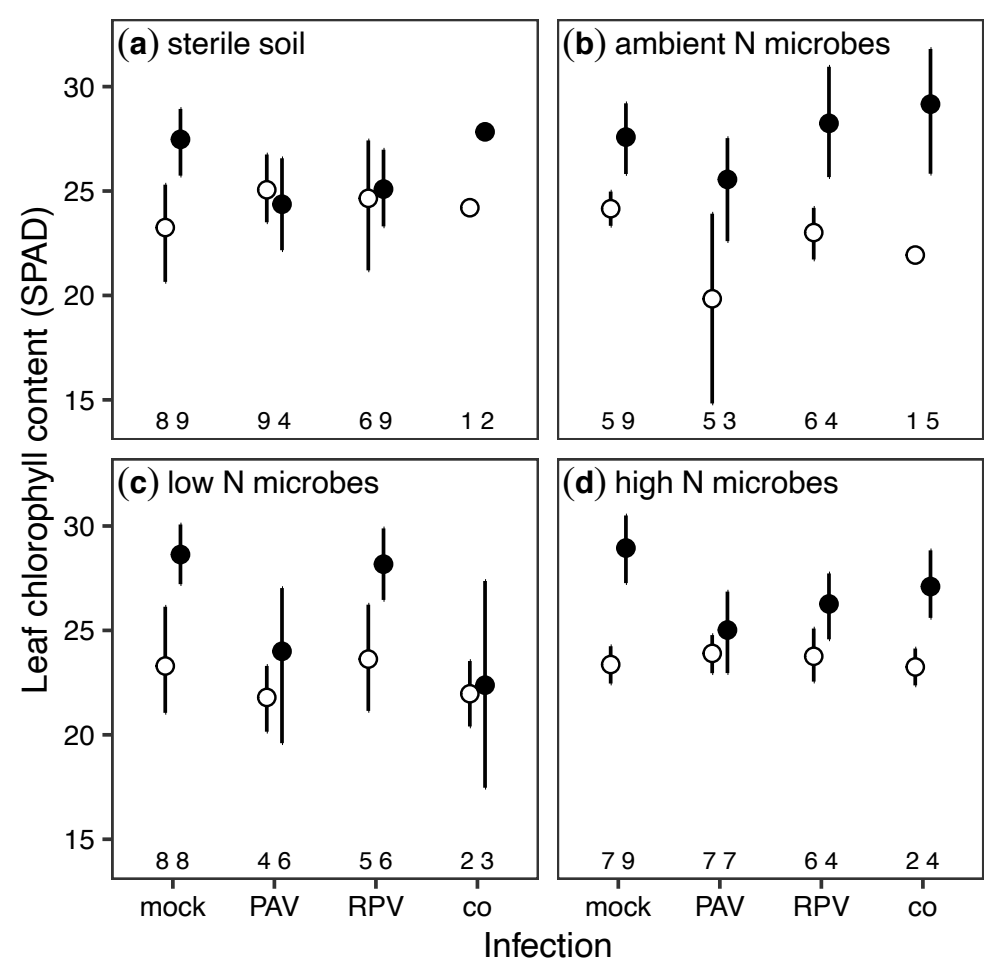

Nitrogen supply $\bigcirc$ low $\bullet$ high

Fig. 5 